\title{
PENINGKATAN HASIL DAN KUALITAS JAGUNG PULUT MELALUI PENGGUNAAN PUPUK ABU SABUT KELAPA
}

\author{
Marianne Reynelda Mamondol ${ }^{1)}$ dan Nurfhin Ilma Bunga ${ }^{2)}$ \\ ${ }^{1 \& 2)}$ Fakultas Pertanian Universitas Kristen Tentena \\ email: mariannemamondol@ymail.com \\ email: nbunga89@gmail.com
}

\begin{abstract}
This research aims to find out the effect and functional relationship of coconut ash organic fertilizer application on the increasing yield and quality of waxy corn. There are seven treatments of coconut ash fertilizer dosage, i.e. 0.00 ton/ha, 0.75 ton/ha, 1.50 ton/ha, 2.25 ton/ha, 3.00 ton/ha, 3.75 ton/ha, and 4.50 ton/ha. Data is analyzed using one way anova, t test for 2 independent samples, and simple linear regression analysis. Fertilizer dosage has significant effect on ear height position from soil surface, the amount of seed row on ear, ear weight with and without leaves, waxy corn production with and without leaves, and starch, amilose, and amilopectin contents. The highest average of ear height position and the amount of seed row is obtained at dosage 0.75 ton/ha. Dosage 2.25 ton/ha gives highest average for ear weight with and without leaves, while dosage 3.75 ton/ha results highest average for variables of waxy corn production with and without leaves. Dosage 3.75 ton/ha also gives highest average for starch and amilopectin contents and lowest average for amilose content. One way relationship happens between fertilizer dosage with ear height position, the amount of seed row, ear weight, waxy corn production, starch and amilopectin contents.
\end{abstract}

Keywords: waxy corn, coconut ash, yield, quality

\section{PENDAHULUAN}

\subsection{Latar Belakang}

Jagung pulut atau jagung ketan (Zea mays ceratina L.) yang dikenal pula dengan sebutan waxy corn termasuk jenis jagung khusus yang dewasa ini semakin banyak dibutuhkan oleh konsumen maupun industri. Jagung khusus memiliki keunggulan berupa kadar yang tinggi dari bahan-bahan fungsional tertentu. Jagung pulut memiliki citarasa yang enak, lebih gurih, pulen, dan lembut. Citarasa ini muncul karena kandungan amilopektin yang tinggi di dalam biji jagung pulut sebesar $90 \%$ atau bahkan dapat mencapai $100 \%$ (Suarni, 2009).

Jagung pulut merupakan bahan pangan khas Pulau Sulawesi. Masyarakat Sulawesi umumnya sangat menggemari jagung pulut yang dapat dikreasikan dalam berbagai bentuk makanan olahan. Selain itu jagung pulut juga menjadi sumber plasma nutfah untuk merakit kultivarkultivar baru melalui kegiatan pemuliaan tanaman (Azrai et al, 2009). Permintaan pasar jagung pulut terus meningkat, namun hal ini tidak bisa diimbangi dengan produksi. Menurut Suarni (2013), jagung pulut lokal Sulawesi memiliki produktivitas yang hanya mencapai 2 hingga 2,5 ton/ha, sementara potensi hasil bisa mencapai 8,09 ton/ha. Di Kabupaten Poso pada tahun 2012 produksi jagung pulut hanya mencapai $3.731,2$ ton, lebih rendah jika dibandingkan dengan produksi di tingkat Provinsi Sulawesi Tengah sebesar 440.308 ton (BPS Poso, 2013).

Upaya peningkatan produksi tanaman dapat dilakukan dengan cara memperluas areal penanaman, meningkatkan produktivitas tanaman, mempertahankan stabilitas produksi, menekan kesenjangan hasil, dan menurunkan kehilangan hasil. Selain itu upaya peningkatan produktivitas tanaman juga sangat bergantung pada kemampuan penyediaan dan penerapan teknologi budidaya yang sesuai dengan anjuran, seperti penggunaan pupuk.

Pemberian pupuk dengan dosis yang tepat merupakan salah satu cara yang dapat dilakukan untuk meningkatkan 
produksi jagung pulut. Pemupukan merupakan tindakan pemberian unsur hara pada tanaman melalui tanah sebagai media tumbuh tanaman. Kalium (K) termasuk unsur hara makro yang sangat esensial bagi pertumbuhan dan produksi tanaman. Jumin (2010) mengemukakan bahwa unsur $\mathrm{K}$ diperlukan untuk pembentukan karbohidrat dan proses translokasi gula dalam tanaman serta menambah bobot biji pada tanaman serealia sehingga menjadi lebih bernas.

Pemupukan $\mathrm{K}$ dapat pula dilakukan secara organik dengan memanfaatkan bahan-bahan alami yang bertujuan meningkatkan pertumbuhan dan produksi tanaman, memperbaiki sifat kimia, fisika, dan biologi tanah, serta menghindari pencemaran karena sifatnya yang ramah lingkungan (Nurhayati et al, 2011). Terdapat bahan-bahan alami yang kaya akan kandungan unsur $\mathrm{K}$, di antaranya ialah sabut kelapa. Kabupaten Poso merupakan daerah penghasil komoditas kelapa, akan tetapi sabut kelapa umumnya masih merupakan limbah pertanian yang belum banyak diketahui manfaatnya oleh masyarakat. Padahal sabut kelapa dapat pula diolah menjadi bahan baku pembuatan pupuk organik yang dapat diaplikasikan pada tanaman budidaya (Hermawati, 2007).

Berdasarkan uraian tersebut maka perlu dilakukan penelitian penggunaan abu sabut kelapa sebagai pupuk kalium organik dengan dosis tertentu pada tanaman jagung pulut dan mengamati pengaruh pemupukan tersebut terhadap peningkatan hasil dan kualitas tanaman.

\subsection{Tujuan Penelitian}

Adapun tujuan penelitian ini ialah untuk : 1) mengetahui pengaruh penggunaan dosis pupuk abu sabut kelapa terhadap peningkatan hasil dan kualitas jagung pulut, dan 2) mengetahui hubungan fungsional antara dosis pupuk organik abu sabut kelapa dengan hasil dan kualitas jagung pulut.

\section{TINJAUAN PUSTAKA}

\subsection{Karakteristik Biji Jagung Pulut}

Jagung pulut atau jagung ketan (waxy corn) merupakan salah satu jenis jagung yang sering dijadikan sebagai makanan pokok pengganti nasi oleh masyarakat di Pulau Sulawesi. Jagung pulut sangat digemari karena rasanya seperti ketan, lebih gurih dan enak dibandingkan dengan jenis jagung lainnya. Jagung pulut dikonsumsi dengan cara tongkolnya direbus atau dibakar, atau dibuat jagung pipilan dan direbus dengan sayuran (Suarni, 2009).

Rasa gurih pada jagung pulut disebabkan oleh kadar amilopektin dalam biji jagung yang mencapai 93 hingga 100 $\%$ dari bobot biji (Suarni, 2009). Amilopektin merupakan polisakarida yang panjang dan bercabang serta digabungkan oleh ikatan glikosidik $\alpha(1 \rightarrow 4)$ pada rantai lurusnya dan ikatan $\alpha-1,6$ pada percabangannya (Lakitan, 2011). Kadar amilopektin mempengaruhi tekstur dan rasa jagung pulut. Pada prinsipnya, semakin tinggi kandungan amilopektin, tekstur dan rasa jagung pulut semakin lunak, pulen, dan enak. Kandungan amilopektin yang tinggi menyebabkan jagung pulut mengandung serat pangan yang tinggi pula. Serat pangan berperan penting dalam memelihara kesehatan individu (Suarni, 2009).

\subsection{Pemupukan K Organik pada Tanaman}

Menurut Farizaldi (2014), pemupukan $\mathrm{K}$ pada tanaman bermanfaat untuk meningkatkan vigor tanaman, membuat tanaman lebih tahan terhadap penyakit, menghasilkan perakaran tanaman yang lebih baik, mengurangi efek negatif akibat pemupukan Nitrogen $(\mathrm{N})$, mempengaruhi waktu pemasakan yang mungkin terlampau cepat oleh pemupukan Fosfor (P), mengatur keseimbangan pupuk $\mathrm{N}$ dan $\mathrm{P}$ khususnya pada pemupukan campuran, membantu pembentukan karbohidrat dan proses translokasi gula dalam tanaman, membantu pembentukan klorofil, dan menambah bobot biji serealia sehingga hasil tanaman menjadi lebih bernas.

Pradana et al (2015) menyatakan bahwa unsur $\mathrm{K}$ diserap tanaman dalam bentuk ion $\mathrm{K}^{+}$, di mana unsur ini terdapat pada tanah dalam persenyawaan kompleks dan diikat oleh mineral atau larutan garam. Peningkatan pemakaian pupuk $\mathrm{N}$ dan $\mathrm{P}$ umumnya akan meningkatkan pula penggunaan pupuk K. Pupuk K 
memberikan pengaruh yang nyata pada tanah kering, tetapi pada tanah sawah pupuk $\mathrm{K}$ tidak memperlihatkan pengaruh nyata. Unsur $\mathrm{K}$ mempunyai ciri khusus jika dibandingkan dengan unsur-unsur lainnya, di mana kelebihan $\mathrm{K}$ dalam tanah tidak berpengaruh negatif terhadap tanaman. Hal ini menjadi penyebab kehilangan $\mathrm{K}$ dalam tanah jauh lebih besar daripada yang diduga karena tanaman dapat menyerap K melebihi dari kebutuhan yang sebenarnya.

Usaha untuk meningkatkan produktivitas tanaman dengan pemupukan sering terhambat oleh mahalnya harga pupuk kimia sintetik atau ketersediannya yang sering mengalami kelangkaan. Karena itu salah satu solusi untuk mencari pupuk alternatif yang dapat mensubstitusi penggunaan pupuk kimia sintetik dengan harga yang murah dan mudah diperoleh ialah dengan memanfaatkan sisa atau limbah tanaman. Limbah tanaman merupakan sumber bahan organik bagi tanah. Penggunaan limbah tanaman sebagai pupuk mudah dilaksanakan dan cukup menguntungkan karena tersedia di alam sekitar. Sabut kelapa merupakan contoh limbah tanaman yang dapat dimanfaatkan sebagai pupuk organik (Oktavia, 2013). Limbah sabut kelapa mengandung unsur $\mathrm{K}$ cukup tinggi. Oleh karena itu limbah sabut kelapa dapat digunakan sebagai sumber nabati $\mathrm{K}$ untuk diolah menjadi pupuk K. Pengambilan senyawa $\mathrm{K}$ dari limbah pertanian dilakukan menjadi abu sehingga garamgaram organik yang terkandung di dalamnya berubah menjadi kalium karbonat (Maesaroh et al, 2014).

Ekawati dan Purwanto (2012) menunjukkan bahwa sabut kelapa mengandung $10,25 \% \mathrm{~K}$. Selain itu sabut kelapa juga mengandung senyawasenyawa karbohidrat lainnya berupa pektin $(14,06 \%)$, hemiselulosa $(7,69 \%)$, lignin $(30,02 \%)$, dan selulosa (Maesaroh et al, 2014).

Hasil penelitian Maruapey dan Faesal (2010) memperlihatkan bahwa dosis pupuk $\mathrm{KCl}$ sebesar $100 \mathrm{~kg} / \mathrm{ha}$ memberikan produksi yang tertinggi dari jagung pulut yaitu sebanyak 4,35 ton/ha. Dosis pupuk $\mathrm{KCl}$ sebesar $75 \mathrm{~kg} / \mathrm{ha}$ berpengaruh nyata pada tinggi tanaman, di mana pada umur tanaman 4 MST diperoleh rata-rata tinggi tanaman $91,82 \mathrm{~cm}$, sedang pada umur tanaman 8 MST diperoleh ratarata tinggi tanaman $199,46 \mathrm{~cm}$. Dosis pupuk $\mathrm{KCl}$ sebesar $100 \mathrm{~kg} / \mathrm{ha}$ menghasilkan umur berbunga tercepat yaitu 29 HST, rata-rata kadar amilopektin sebesar 74,21\%, dan biomassa tertinggi sebesar 11,01 ton/ha.

Menurut Risnah et al (2013), penggunaan abu sabut kelapa sebagai alternatif pupuk $\mathrm{KCl}$ dapat meningkatkan ketersediaan $\mathrm{K}$ pada tanah dan serapan $\mathrm{K}$ pada pertumbuhan bibit kakao. Dosis pupuk organik abu sabut kelapa sebesar 39,25 g per tanaman efektif meningkatkan $\mathrm{K}$ tersedia pada tanah hingga umur bibit kakao mencapai 4 bulan setelah penanaman. Adapun rata-rata jumlah $\mathrm{K}$ tersedia pada penggunaan abu sebanyak $39,25 \mathrm{~g}$ ialah mencapai 2,66 me/100 g tanah. Menurut Jumin (2010) ketersediaan $\mathrm{K}$ dalam tanah dikatakan tinggi jika kadarnya di atas $0,64 \mathrm{me} / 100 \mathrm{~g}$ tanah. Dosis abu sebanyak 39,25 g juga menghasilkan serapan $\mathrm{K}$ tertinggi pada jaringan tanaman berupa daun, batang, dan akar yaitu sebesar 12,35 mg/tanaman.

Hasil penelitian Risnah et al (2013) juga menunjukkan bahwa sesudah aplikasi pupuk organik abu sabut kelapa terjadi peningkatan $\mathrm{pH}$ pada media tanam. Peningkatan $\mathrm{pH}$ kemungkinan disebabkan karena abu sabut kelapa memiliki $\mathrm{pH}$ tinggi dan didominasi oleh ion basa $\mathrm{OH}^{-}$. Setelah diaplikasikan pada media tanam tanah inceptisol yang memiliki ion $\mathrm{H}^{+}$ lebih banyak maka pemberian abu sabut kelapa dapat meningkatkan konsentrasi ion $\mathrm{OH}^{-}$. Dengan demikian maka konsentrasi ion $\mathrm{H}^{+}$dan $\mathrm{OH}^{-}$dalam larutan tanah menjadi lebih seimbang dan $\mathrm{pH}$ tanah bereaksi netral. Pemberian abu sabut kelapa dengan dosis $39,25 \mathrm{~g}$ per tanaman memberikan $\mathrm{pH}$ tanah rata-rata sebesar 7,05. Di samping itu, hasil analisis abu sabut kelapa yang dilakukan oleh Risnah $e t$ al (2013) menunjukkan bahwa abu sabut kelapa memiliki kapasitas pertukaran kation yang baik, yaitu 13,29 me/100 g. Menurut Soemeinaboedhy dan Tejowulan (2007), semakin tinggi nilai KPK maka pertukaran kation semakin banyak dan ini berarti pelepasan unsurnya juga semakin besar. Dengan demikian abu sabut kelapa 
merupakan bahan yang potensial sebagai pupuk organik pada tanaman.

Penelitian yang dilakukan oleh Nurmas (2008) memperlihatkan bahwa pupuk organik abu sabut kelapa dengan dosis antara 1,0 sampai 2,5 ton/ha memberikan perbedaan nyata terhadap komponen pertumbuhan tanaman ketimun berupa diameter batang dan luas daun dan komponen hasil berupa panjang dan berat buah ketimun segar. Hal ini disebabkan karena pemberian abu sabut kelapa mampu memperbaiki sifat fisik tanah, menetralkan $\mathrm{pH}$ tanah, dan menyediakan unsur hara bagi tanaman. Hermawati (2007) menyatakan bahwa abu sabut kelapa dengan dosis 3 ton/ha menunjukkan pengaruh yang signifikan terhadap pertumbuhan dan hasil tanaman semangka yang meliputi komponen pengamatan berupa luas daun total, berat kering akar, umur pembentukan bunga pertama, dan bobot buah.

Penelitian lainnya yang dilakukan oleh Maesaroh et al (2014) menunjukkan bahwa ekstrak abu sabut kelapa dengan konsentrasi $100 \mathrm{ml}$ memberikan perbedaan nyata pada pertumbuhan awal tanaman jagung manis yang meliputi tinggi tanaman dan jumlah daun. Menurut Nurvitha (2016), K berperan dalam pembentukan protein dan karbohidrat, di mana $\mathrm{K}$ yang diserap oleh tanaman dalam bentuk $\mathrm{K}^{+}$ terutama pada sel-sel muda atau pada bagian tanaman yang banyak mengandung protein.

\section{METODE PENELITIAN}

\subsection{Waktu dan Tempat Penelitian}

Penelitian ini dilaksanakan pada bulan Juli hingga September 2017 bertempat di Kebun Percobaan Fakultas Pertanian Universitas Kristen Tentena. Uji laboratorium dilaksanakan di Laboratorium Ilmu Tanah dan Laboratorium Teknologi Hasil Pangan (THP) Fakultas Pertanian Universitas Tadulako Palu pada bulan September hingga Oktober 2017.

\subsection{Bahan dan Alat}

Bahan-bahan yang digunakan dalam penelitian ini ialah benih jagung pulut varietas lokal, sabut kelapa, pupuk kandang, kayu bakar, insektisida Furadan
3G, dan fungisida Dithane M-45. Alat-alat yang digunakan dalam penelitian ini ialah timbangan analitik, meteran, selang air, pacul, garu, sprayer, tugal, drum, dan papan label perlakuan.

\subsection{Pelaksanaan Penelitian}

\subsubsection{Analisis Kimia Pupuk Organik}

Analisis terhadap pupuk organik abu sabut kelapa dilakukan dengan mengukur pH, Kalium (K) total, C organik, Kapasitas Tukar Kation (KTK), kadar air, dan C/N Ratio.

\subsubsection{Pembuatan Abu Sabut Kelapa}

Sabut kelapa dibelah-belah menjadi berukuran kecil-kecil untuk memudahkan pembakaran. Setelah dibelah sabut kelapa dimasukkan ke dalam drum dengan cara disusun satu persatu. Pada bagian dasar drum diberi kayu bakar, sedangkan bagian mulut drum ditutup agar pembakaran sabut kelapa terjadi secara perlahan-lahan sehingga diperoleh abu dengan kualitas yang baik. Abu yang terbentuk dari hasil pembakaran selanjutnya didinginkan.

\subsubsection{Pengolahan Lahan dan \\ Penanaman}

Tanah dibajak, dipacul, digaru, dicampurkan dengan pupuk kandang, lalu dibuat bedengan dengan ukuran 2,1 x 1,5 $\mathrm{m}$. Abu dicampurkan dengan tanah sesuai dosis yang telah ditetapkan untuk setiap petak perlakuan. Bedengan kemudian dibiarkan selama 3 hari sebelum dilakukan penanaman. Benih jagung pulut ditanam dengan cara ditugal. Jarak tanam yang digunakan ialah $40 \times 30 \mathrm{~cm}$.

\subsubsection{Pemberian Perlakuan}

Perlakuan pupuk organik abu sabut kelapa dalam penelitian ini terdiri dari :

$$
\begin{array}{ll}
\mathrm{A}_{0} & =\text { Dosis } 0,00 \text { ton } / \mathrm{ha} \\
\mathrm{A}_{1} & =\text { Dosis } 0,75 \text { ton } / \mathrm{ha} \\
\mathrm{A}_{2} & =\text { Dosis } 1,50 \text { ton } / \mathrm{ha} \\
\mathrm{A}_{3} & =\text { Dosis } 2,25 \text { ton/ha } \\
\mathrm{A}_{4} & =\text { Dosis } 3,00 \text { ton/ha } \\
\mathrm{A}_{5} & =\text { Dosis } 3,75 \text { ton } / \mathrm{ha} \\
\mathrm{A}_{6} & =\text { Dosis } 4,50 \mathrm{ton} / \mathrm{ha}
\end{array}
$$

Terdapat 7 petak perlakuan di mana setiap perlakuan diulang sebanyak 3 kali, dengan 
demikian secara keseluruhan terdapat 21 petak percobaan.

\subsubsection{Pemeliharaan dan Panen}

Pemeliharaan tanaman meliputi penyiraman, penyiangan gulma, serta pengendalian hama dan penyakit tanaman. Panen dilakukan setelah tanaman jagung berumur 80 hari setelah tanam (HST).

\subsection{Komponen Pengamatan}

Komponen-komponen yang diamati di dalam penelitian ini ialah :

1. Komponen hasil, meliputi tinggi kedudukan tongkol dari permukaan tanah (cm), jumlah tongkol per tanaman, panjang tongkol $(\mathrm{cm})$, jumlah baris biji pada tongkol, jumlah biji per tongkol, bobot per tongkol dengan klobot $(\mathrm{g})$, bobot per tongkol tanpa klobot (g), produksi jagung pulut dengan klobot (ton/ha), dan produksi jagung pulut tanpa klobot (ton/ha).
2. Komponen kualitas, meliputi kadar pati (\%), kadar amilosa, (\%), dan kadar amilopektin pada biji (\%).

\subsection{Analisis Data}

Data yang telah terkumpul selanjutnya dianalisis dengan menggunakan teknik analisis varians satu jalan (one way anova), uji t 2 sampel independen, dan teknik regresi linear sederhana dengan model persamaan $\mathrm{Y}=\mathrm{a}+\mathrm{bX}$.

\section{HASIL DAN PEMBAHASAN}

\subsection{Analisis Kimia Pupuk Organik}

Berdasarkan pengujian laboratorium maka diperoleh hasil analisis kimia pupuk organik abu sabut kelapa sebagai berikut :

TABEL 1. Hasil Analisis Kimia Pupuk Organik Abu Sabut Kelapa

\begin{tabular}{clcc}
\hline No. & Parameter & Nilai & Satuan \\
\hline 1. & pH & 9,69 & - \\
2. & K total & 10,12 & $\%$ \\
3. & C-organik & 11,24 & $\%$ \\
4. & KTK & 20,72 & $\mathrm{cmol}^{(+)} \mathrm{kg}^{-1}$ \\
5. & Kadar air & 29,63 & $\%$ \\
6. & C/N Ratio & 36,65 & - \\
\hline
\end{tabular}

Adapun persyaratan teknis minimal pupuk organik padat berbentuk remah/curah menurut Kementerian Pertanian RI (2011) ialah sebagai berikut :

TABEL 2. Persyaratan Teknis Minimal Pupuk

Organik Padat Berbentuk Remah/

Curah

\begin{tabular}{|c|c|c|c|}
\hline No. & Parameter & Nilai & Satuan \\
\hline 1. & $\mathrm{pH}$ & $4-9$ & - \\
\hline 2. & $\mathrm{~K}$ total & minimal 4 & $\%$ \\
\hline 3. & C-organik & minimal 15 & $\%$ \\
\hline 4. & KTK & - & $\operatorname{cmol}(+) \mathrm{kg}^{-1}$ \\
\hline 5. & Kadar air & $15-25$ & $\%$ \\
\hline 6. & C/N Ratio & $15-25$ & - \\
\hline
\end{tabular}

Jika dibandingkan antara datadata yang terdapat pada Tabel 1 dan Tabel 2 akan terlihat bahwa terdapat beberapa parameter pada Tabel 1 yang nilainya tidak memenuhi standar mutu sebagaimana yang ditetapkan pada Tabel
2. Hal ini berarti bahwa untuk menjadi sebuah produk pupuk organik yang berkualitas dan memenuhi persyaratan teknis minimal maka proses pengolahan sabut kelapa menjadi abu perlu diteliti dan dikaji lebih lanjut guna memperoleh suatu 
prosedur standar dan parameter-parameter yang diuji juga mampu memenuhi spesifikasi sesuai ketetapan pemerintah.

Secara umum dapat dilihat bahwa abu sabut kelapa memiliki sifat basa dengan $\mathrm{pH}$ sebesar 9,69. Dengan demikian abu sabut kelapa berpotensi untuk meningkatkan $\mathrm{pH}$ pada tanah-tanah yang memiliki tingkat keasaman tinggi seperti tanah gambut (Nurvitha, 2016), tanah podzolik merah kuning (Hermawati, 2007), atau tanah ultisol (Farizaldi, 2014). Nilai $\mathrm{K}$ total sebesar 10,12\% menunjukkan bahwa abu sabut kelapa mengandung unsur hara kalium dalam jumlah yang besar, walaupun kandungan bahan organiknya rendah yaitu sebesar $11,24 \%$.

Kapasitas pertukaran kation abu sabut kelapa sebesar $20,72 \mathrm{cmol}(+) \mathrm{kg}^{-1}$ cukup besar jika dibandingkan bahanbahan lain seperti kayu $\left(3,47 \mathrm{cmol}(+) \mathrm{kg}^{-1}\right)$, sekam padi $\left(16,70 \mathrm{cmol}(+) \mathrm{kg}^{-1}\right)$, atau serbuk gergaji $\left(18,36 \mathrm{cmol}(+) \mathrm{kg}^{-1}\right)$. Soemeinaboedhy dan Tejowulan (2007) menyatakan bahwa abu sabut kelapa memiliki total luas permukaan yang besar dibandingkan bahan-bahan lainnya sehingga permukaan yang mungkin melakukan pertukaran kation menjadi lebih banyak. Kadar air abu sabut kelapa sebesar 29,63\% lebih tinggi dibandingkan standar mutu sebesar $15-25 \%$. Diduga ini berkaitan dengan sifat sabut kelapa yang mudah menyerap dan menyimpan air (Lestari, 2016). Selain itu menurut Dianawati (2014), abu sabut kelapa memiliki porositas tinggi, artinya mampu mengikat cairan dalam pori-porinya.

Rasio C/N pada abu sabut kelapa sebesar 36,65 \% yang juga lebih tinggi daripada standar mutu $(15-25 \%)$ menunjukkan tingkat kematangan pupuk yang belum optimal. Dewi dan Tambingsila (2014) menyatakan bahwa rasio $\mathrm{C} / \mathrm{N}$ berpengaruh pada pertumbuhan tanaman karena untuk merombak bahan organik pada pupuk organik bakteri dekomposer membutuhkan unsur hara $\mathrm{N}$ yang lebih banyak.

\subsection{Komponen Hasil Tanaman Jagung Pulut}

1) Tinggi kedudukan tongkol dari permukaan tanah
Hasil analisis varians satu arah menunjukkan bahwa perlakuan dosis pupuk organik abu sabut kelapa berpengaruh nyata terhadap tinggi kedudukan tongkol dari permukaan tanah. Hasil uji t 2 sampel independen ialah sebagai berikut :

TABEL 3. Rata-rata Tinggi Kedudukan Tongkol dari Permukaan Tanah

\begin{tabular}{cc}
$\begin{array}{c}\text { Dosis pupuk } \\
\text { organik } \\
\text { abu sabut kelapa }\end{array}$ & $\begin{array}{c}\text { Rata-rata tinggi } \\
\text { kedudukan } \\
\text { tongkol } \\
\text { dari permukaan } \\
\text { tanah }(\mathrm{cm})\end{array}$ \\
\hline $\mathrm{A}_{0}(0,00$ ton/ha) & $64,33^{\mathrm{a}}$ \\
$\mathrm{A}_{1}(0,75$ ton/ha) & $108,00^{\mathrm{b}}$ \\
$\mathrm{A}_{2}(1,50$ ton/ha) & $97,33^{\mathrm{b}}$ \\
$\mathrm{A}_{3}(2,25$ ton/ha) & $107,67^{\mathrm{b}}$ \\
$\mathrm{A}_{4}(3,00$ ton/ha) & $91,00^{\mathrm{c}}$ \\
$\mathrm{A}_{5}(3,75$ ton/ha) & $93,33^{\mathrm{c}}$ \\
$\mathrm{A}_{6}(4,50$ ton/ha) & $90,83^{\mathrm{c}}$ \\
\hline $\mathrm{K}$
\end{tabular}

Keterangan : Angka-angka yang diikuti huruf yang sama tidak berbeda nyata pada $\alpha=0,05$

Hasil uji t menunjukkan bahwa rata-rata tertinggi diperoleh pada perlakuan $\mathrm{A}_{1}$ sebesar $108,00 \mathrm{~cm}$. Hasil analisis regresi linear sederhana menunjukkan hubungan fungsional sebagai berikut :

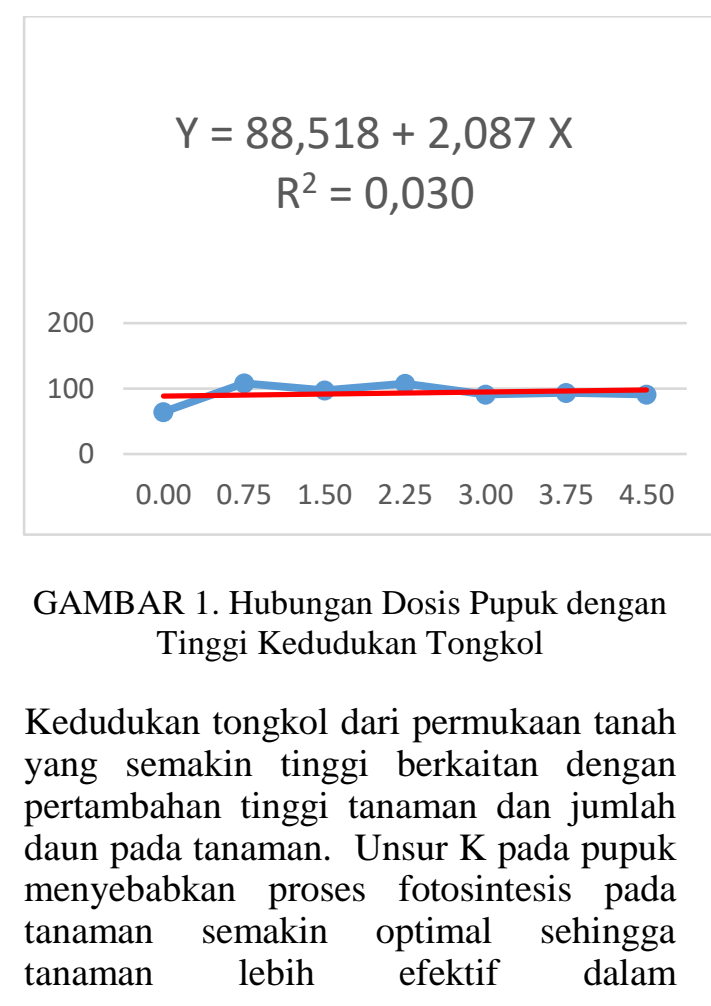


mengakumulasi hasil fotosintesis terutama dari daun yang letaknya di atas posisi tongkol. Sifat ideal bagi tanaman jagung pulut ialah bahwa tongkol berada pada posisi pertengahan, yaitu setengah dari tinggi tanaman (Maruapey dan Faesal, 2010).

\section{2) Jumlah Tongkol per Tanaman}

Hasil analisis varians satu arah memperlihatkan bahwa perlakuan dosis pupuk organik abu sabut kelapa tidak berpengaruh nyata terhadap jumlah tongkol per tanaman. Hasil ini memperlihatkan bahwa tanaman jagung pulut memiliki kemampuan yang relatif sama dalam pembentukan tongkol, walaupun diberikan pupuk dalam dosis yang berbeda. Selain itu diduga pula bahwa pembentukan tongkol lebih terkendali secara genetik (Pandia et al, 2013).

\section{3) Panjang Tongkol}

Hasil analisis varians satu arah memperlihatkan bahwa perlakuan dosis pupuk organik abu sabut kelapa tidak berpengaruh nyata terhadap panjang tongkol. Ukuran panjang tongkol yang relatif sama juga diduga dipengaruhi faktor genetik tanaman, serta didukung oleh kondisi lingkungan yang relatif tidak berbeda.

\section{4) Jumlah Baris Biji pada Tongkol}

Hasil analisis varians satu arah menunjukan bahwa perlakuan dosis pupuk organik abu sabut kelapa berpengaruh nyata terhadap jumlah baris biji pada tongkol. Hasil uji t 2 sampel ialah sebagai berikut :

TABEL 4. Rata-rata Jumlah Baris Biji pada Tongkol

\begin{tabular}{cr}
\hline $\begin{array}{c}\text { Dosis pupuk } \\
\text { organik } \\
\text { abu sabut kelapa }\end{array}$ & $\begin{array}{c}\text { Rata-rata jumlah } \\
\text { baris biji } \\
\text { pada tongkol }\end{array}$ \\
\hline $\mathrm{A}_{0}(0,00$ ton/ha $)$ & $10,00^{\mathrm{a}}$ \\
$\mathrm{A}_{1}(0,75$ ton/ha) & $13,33^{\mathrm{b}}$ \\
$\mathrm{A}_{2}(1,50$ ton/ha) & $12,67^{\mathrm{b}}$ \\
$\mathrm{A}_{3}(2,25$ ton/ha) & $13,00^{\mathrm{b}}$ \\
$\mathrm{A}_{4}(3,00$ ton/ha) & $11,67^{\mathrm{c}}$ \\
$\mathrm{A}_{5}(3,75$ ton/ha) & $12,00^{\mathrm{c}}$ \\
$\mathrm{A}_{6}(4,50$ ton/ha) & $12,00^{\mathrm{c}}$ \\
\hline
\end{tabular}

Keterangan : Angka-angka yang diikuti huruf yang sama tidak berbeda nyata pada $\alpha=0,05$

Hasil uji t menunjukkan bahwa rata-rata tertinggi diperoleh pada perlakuan $\mathrm{A}_{1}$ sebesar 13,33. Hasil analisis regresi linear sederhana ialah sebagai berikut :

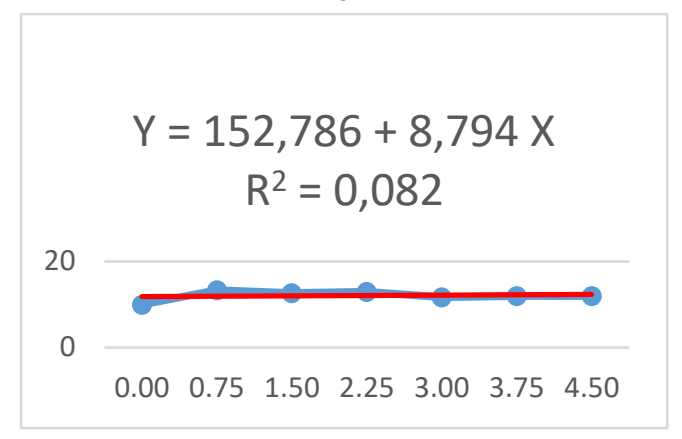

GAMBAR 2. Hubungan Dosis Pupuk dengan Jumlah Baris Biji pada Tongkol

Proses fotosintesis yang semakin optimal seiring dengan peningkatan jumlah unsur $\mathrm{K}$ yang diberikan pada tanah menyebabkan semakin besarnya distribusi fotosintat berupa karbohidrat ke bagian ekonomis tanaman jagung pulut, yaitu bagian tongkol. Ini ditandai dengan semakin banyaknya barisan biji yang terbentuk pada tongkol. Pembentukan barisan biji pada tongkol merupakan penimbunan cadangan makanan yang ditranslokasikan dari bagian daun ke bagian biji tanaman jagung pulut (Maruapey dan Faesal, 2010).

5) Jumlah Biji per Tongkol

Hasil analisis varians satu arah terhadap variabel jumlah biji per tongkol menunjukkan bahwa perlakuan dosis pupuk organik abu sabut kelapa tidak berpengaruh nyata terhadap jumlah biji per tongkol. Dosis pupuk yang berbeda tidak mempengaruhi kemampuan tanaman dalam melakukan pembentukan biji pada tongkol.

6) Bobot per Tongkol dengan Klobot

Hasil analisis varians satu arah memperlihatkan bahwa perlakuan dosis pupuk organik abu sabut kelapa berpengaruh nyata terhadap bobot per tongkol dengan klobot. Hasil uji t 2 sampel independen ialah sebagai berikut : 
TABEL 5. Rata-rata Bobot per Tongkol Dengan Klobot

\begin{tabular}{|c|}
\hline $\begin{array}{l}\text { Rata-rata bobot } \\
\text { per tongkol } \\
\text { dengan klobot } \\
(\mathrm{g})\end{array}$ \\
\hline $\mathrm{A}_{0}(0,00$ ton/ha $)$ \\
\hline $\mathrm{A}_{1}(0,75$ ton/ha $)$ \\
\hline $\mathrm{A}_{2}(1,50$ ton/ha $)$ \\
\hline $\mathrm{A}_{3}(2,25$ ton/ha $)$ \\
\hline $\mathrm{A}_{4}(3,00$ ton $/ \mathrm{ha})$ \\
\hline $\mathrm{A}_{5}(3,75$ ton/ha $)$ \\
\hline $\mathrm{A}_{6}(4,50$ ton/ha $) \quad 158,00^{\mathrm{b}}$ \\
\hline $\begin{array}{c}\text { Keterangan : Angka-angka yang diikuti huruf } \\
\text { yang sama tidak berbeda nyata } \\
\text { pada } \alpha=0,05\end{array}$ \\
\hline $\begin{array}{l}\text { Hasil uji t menunjukkan rata-rata tertinggi } \\
\text { diperoleh pada perlakuan } \mathrm{A}_{3} \text { sebesar } \\
242,67 \mathrm{~g} \text { yang berbeda nyata dengan } \\
\text { kelima perlakuan lainnya. Hasil ini } \\
\text { menegaskan adanya kontribusi unsur } \mathrm{K} \\
\text { dalam meningkatkan pembentukan } \\
\text { karbohidrat melalui proses fotosintesis. } \\
\text { Meningkatnya laju fotosintesis } \\
\text { menyebabkan } \mathrm{CO}_{2} \text { yang diikat lebih } \\
\text { banyak daripada } \mathrm{CO}_{2} \text { yang dilepaskan } \\
\text { dalam proses respirasi. Dengan demikian } \\
\text { maka asimilat yang dihasilkan lebih } \\
\text { banyak berpengaruh terhadap peningkatan } \\
\text { bobot tongkol pada tanaman (Lakitan, } \\
\text { 2011). }\end{array}$ \\
\hline
\end{tabular}

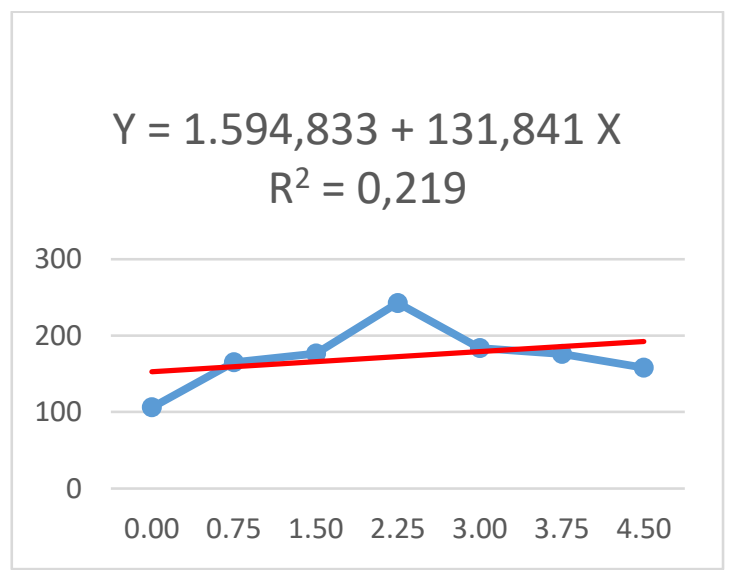

GAMBAR 3. Hubungan Dosis Pupuk dengan Bobot per Tongkol dengan Klobot

7) Bobot per Tongkol Tanpa Klobot Hasil analisis varians satu arah menunjukkan bahwa perlakuan dosis pupuk organik abu sabut kelapa berpengaruh nyata terhadap bobot per tongkol tanpa klobot. Hasil uji t 2 sampel independen ialah :

TABEL 6. Rata-rata Bobot per Tongkol Tanpa

\begin{tabular}{cr}
\multicolumn{2}{c}{ Klobot } \\
\hline $\begin{array}{c}\text { Dosis pupuk } \\
\text { organik } \\
\text { abu sabut kelapa }\end{array}$ & $\begin{array}{c}\text { Rata-rata bobot } \\
\text { per tongkol } \\
\text { tanpa klobot }(\mathrm{g})\end{array}$ \\
\hline $\mathrm{A}_{0}(0,00$ ton/ha) & $67,00^{\mathrm{a}}$ \\
$\mathrm{A}_{1}(0,75$ ton/ha) & $96,33^{\mathrm{b}}$ \\
$\mathrm{A}_{2}(1,50$ ton $/ \mathrm{ha})$ & $115,33^{\mathrm{bd}}$ \\
$\mathrm{A}_{3}(2,25$ ton $/ \mathrm{ha})$ & $127,67^{\mathrm{cd}}$ \\
$\mathrm{A}_{4}(3,00$ ton $/ \mathrm{ha})$ & $112,00^{\mathrm{b}}$ \\
$\mathrm{A}_{5}(3,75$ ton $/ \mathrm{ha})$ & $105,00^{\mathrm{b}}$ \\
$\mathrm{A}_{6}(4,50$ ton/ha $)$ & $121,00^{\mathrm{c}}$ \\
\hline Keterangan : Angka-angka yang diikuti huruf \\
yang sama tidak berbeda nyata \\
pada $\alpha=0,05$
\end{tabular}

Hasil uji t menunjukkan bahwa rata-rata tertinggi diperoleh pada perlakuan $\mathrm{A}_{3}$ sebesar 127,67 g. Hasil analisis regresi linear sederhana ialah sebagai berikut :

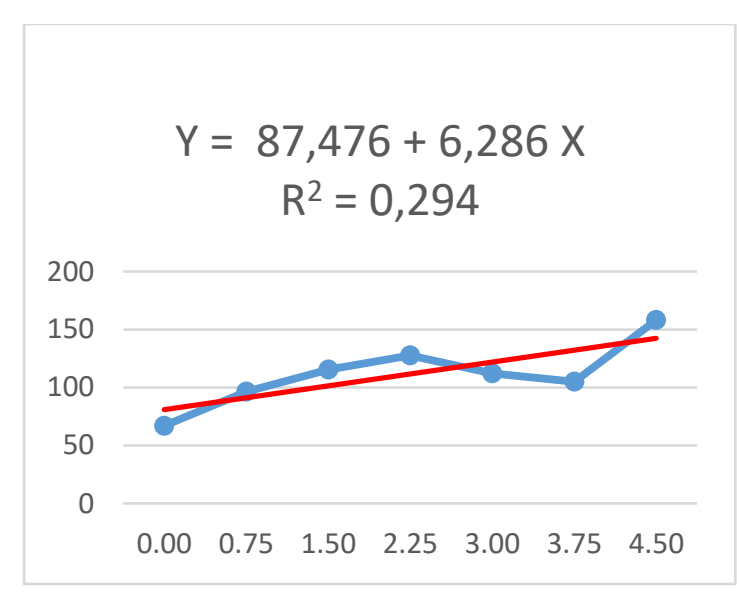

GAMBAR 4. Hubungan Dosis Pupuk dengan Bobot per Tongkol Tanpa Klobot

Aplikasi pupuk lebih memberikan pengaruh pada pertambahan bobot tongkol dibandingkan dengan bobot klobot tanaman jagung pulut. Unsur kalium pada pupuk abu sabut kelapa menyebabkan pengisian biji dengan karbohidrat semakin besar, sehingga ukuran biji bertambah besar, tongkol terisi padat dengan biji, dan bobot tongkol semakin bertambah.

8) Produksi Jagung Pulut Dengan Klobot

Hasil analisis varians satu arah menunjukkan bahwa perlakuan dosis pupuk organik abu sabut kelapa 
berpengaruh nyata terhadap produksi jagung pulut dengan klobot. Hasil uji t 2 sampel independen ialah sebagai berikut :

TABEL 7. Rata-rata Produksi Jagung Pulut Dengan Klobot

\begin{tabular}{cc}
\hline $\begin{array}{c}\text { Dosis pupuk } \\
\text { organik } \\
\text { abu sabut kelapa }\end{array}$ & $\begin{array}{c}\text { Rata-rata } \\
\text { produksi jagung } \\
\text { pulut } \\
\text { dengan klobot } \\
\text { (ton / ha) }\end{array}$ \\
\hline $\mathrm{A}_{0}(0,00$ ton/ha) & $3,63^{\mathrm{a}}$ \\
$\mathrm{A}_{1}(0,75$ ton/ha) & $6,75^{\mathrm{b}}$ \\
$\mathrm{A}_{2}(1,50$ ton/ha) & $6,13^{\mathrm{b}}$ \\
$\mathrm{A}_{3}(2,25$ ton/ha) & $6,40^{\mathrm{b}}$ \\
$\mathrm{A}_{4}(3,00$ ton/ha) & $5,64^{\mathrm{c}}$ \\
$\mathrm{A}_{5}(3,75$ ton/ha) & $6,84^{\mathrm{b}}$ \\
$\mathrm{A}_{6}(4,50$ ton/ha) & $6,66^{\mathrm{b}}$ \\
\hline Keterangan : Angka-angka yang diikuti huruf \\
\multicolumn{2}{c}{ yang sama tidak berbeda nyata } \\
pada $\alpha=0,05$
\end{tabular}

Hasil uji t menunjukkan bahwa perlakuan $\mathrm{A}_{1}$ hingga $\mathrm{A}_{6}$ memberikan rata-rata produksi jagung pulut dengan klobot yang berbeda nyata dibandingkan $\mathrm{A}_{0}$ dengan rata-rata tertinggi diperoleh pada perlakuan $\mathrm{A}_{5}$ sebesar 6,84 ton/ha. Hasil analisis regresi linear sederhana ialah sebagai berikut :

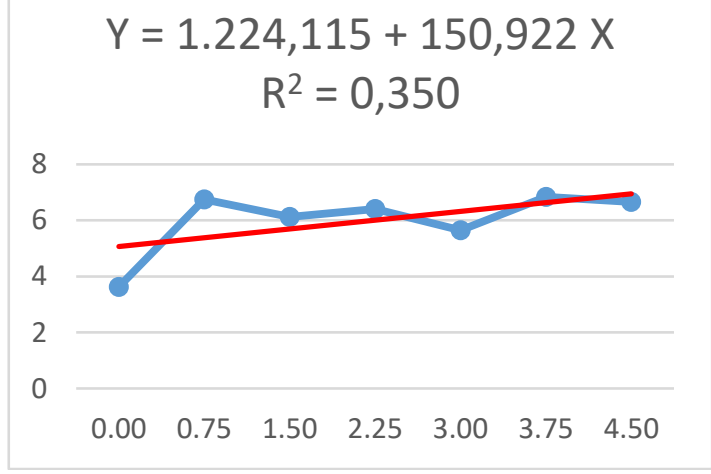

GAMBAR 5. Hubungan Dosis Pupuk dengan Produksi Jagung Pulut Dengan Klobot

9) Produksi Jagung Pulut Tanpa Klobot

Hasil analisis varians memperlihatkan bahwa perlakuan dosis pupuk organik abu sabut kelapa berpengaruh nyata terhadap produksi jagung pulut tanpa klobot. Hasil uji t 2 sampel independen ialah sebagai berikut :
TABEL 8. Rata-rata Produksi Jagung Pulut Tanpa Klobot

\begin{tabular}{cc}
\hline $\begin{array}{c}\text { Dosis pupuk } \\
\text { organik } \\
\text { abu sabut kelapa }\end{array}$ & $\begin{array}{c}\text { Rata-rata } \\
\text { produksi jagung } \\
\text { pulut } \\
\text { tanpa klobot } \\
\text { (ton/ha) }\end{array}$ \\
\hline $\mathrm{A}_{0}(0,00$ ton/ha) & $2,39^{\mathrm{a}}$ \\
$\mathrm{A}_{1}(0,75$ ton/ha) & $5,06^{\mathrm{b}}$ \\
$\mathrm{A}_{2}(1,50$ ton/ha) & $5,05^{\mathrm{b}}$ \\
$\mathrm{A}_{3}(2,25$ ton/ha) & $5,37^{\mathrm{b}}$ \\
$\mathrm{A}_{4}(3,00$ ton/ha) & $4,71^{\mathrm{c}}$ \\
$\mathrm{A}_{5}(3,75$ ton $/ \mathrm{ha})$ & $5,94^{\mathrm{b}}$ \\
$\mathrm{A}_{6}(4,50$ ton/ha) & $5,82^{\mathrm{b}}$ \\
\hline
\end{tabular}

Keterangan : Angka-angka yang diikuti huruf yang sama tidak berbeda nyata pada $\alpha=0,05$

Hasil uji t menunjukkan bahwa rata-rata tertinggi diperoleh pada perlakuan $\mathrm{A}_{5}$ sebesar 5,94 ton/ha. Peran unsur K dalam memperbaiki pertumbuhan dan hasil tanaman dapat terlihat dalam peningkatan produksi jagung pulut dengan dan tanpa klobot. Peningkatan dosis pupuk abu sabut kelapa menyebabkan proses fisiologis tanaman berjalan lebih baik. Hal tersebut dikarenakan peran unsur $\mathrm{K}$ sebagai aktivator enzim yang sangat penting dalam reaksi-reaksi fisiologis dan menyebabkan penimbunan fotosintat berjalan optimal sehingga menghasilkan biomassa tanaman yang lebih berat (Pandia et al, 2013).

$$
\begin{gathered}
Y=1 \cdot 224,115+150,922 X \\
R^{2}=0,350
\end{gathered}
$$

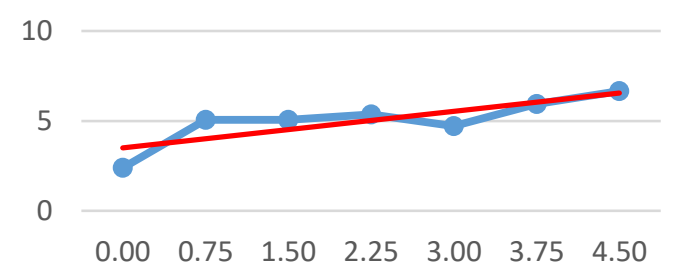

GAMBAR 6. Hubungan Dosis Pupuk dengan Produksi Jagung Pulut Tanpa Klobot 


\section{Komponen Kualitas Tanaman Jagung Pulut}

1) Kadar pati pada biji jagung pulut Hasil analisis varians satu arah memperlihatkan bahwa perlakuan dosis pupuk organik abu sabut kelapa berpengaruh nyata terhadap kadar pati pada biji jagung pulut. Hasil uji lanjut dengan uji t 2 sampel independen ialah sebagai berikut :

TABEL 9. Rata-rata Kadar Pati pada Biji

\begin{tabular}{cr}
\hline $\begin{array}{c}\text { Dosis pupuk } \\
\text { organik } \\
\text { abu sabut kelapa }\end{array}$ & $\begin{array}{c}\text { Rata-rata kadar } \\
\text { pati pada biji } \\
(\%)\end{array}$ \\
\hline $\mathrm{A}_{0}(0,00$ ton/ha) & $25,884^{\mathrm{a}}$ \\
$\mathrm{A}_{1}(0,75$ ton/ha) & $26,631^{\mathrm{b}}$ \\
$\mathrm{A}_{2}(1,50$ ton/ha) & $30,257^{\mathrm{c}}$ \\
$\mathrm{A}_{3}(2,25$ ton/ha) & $38,749^{\mathrm{d}}$ \\
$\mathrm{A}_{4}(3,00$ ton/ha) & $38,812^{\mathrm{d}}$ \\
$\mathrm{A}_{5}(3,75$ ton/ha) & $51,892^{\mathrm{e}}$ \\
$\mathrm{A}_{6}(4,50$ ton/ha) & $50,587^{\mathrm{f}}$ \\
\hline
\end{tabular}

Keterangan : Angka-angka yang diikuti huruf yang sama tidak berbeda nyata pada $\alpha=0,05$

Hasil uji t menunjukkan bahwa perlakuan $\mathrm{A}_{5}$ memberikan rata-rata kadar pati tertinggi $(51,892 \%)$ yang berbeda nyata dengan perlakuan-perlakuan lainnya. Secara fisiologis, kalium yang terkandung dalam abu sabut kelapa berfungsi dalam membentuk dan mengangkut karbohidrat ke bagian biji tanaman. Apabila tanaman kekurangan unsur kalium maka akan terjadi akumulasi karbohidrat pada bagian daun yang dapat berakibat menurunnya kadar pati dalam biji (Maruapey dan Faesal, 2010). Pati merupakan komponen utama pada biji jagung, yaitu sekitar $70 \%$ dari bobot biji (Yasin et al, 2014).

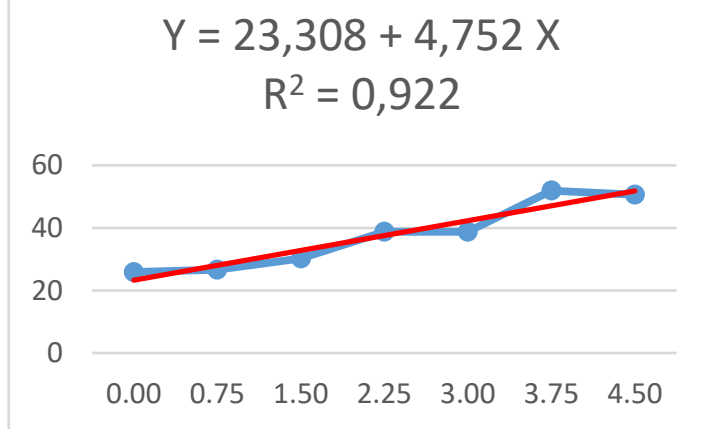

GAMBAR 7. Hubungan Dosis Pupuk dengan Kadar Pati pada Biji Jagung Pulut
2) Kadar Amilosa pada Biji Jagung Pulut Hasil analisis varians memperlihatkan bahwa perlakuan dosis pupuk organik abu sabut kelapa berpengaruh nyata terhadap kadar amilosa pada biji jagung pulut. Hasil uji t 2 sampel independen ialah sebagai berikut :

TABEL 10. Rata-rata Kadar Amilosa pada Biji

Jagung Pulut

\begin{tabular}{cr}
\hline $\begin{array}{c}\text { Dosis pupuk } \\
\text { organik } \\
\text { abu sabut kelapa }\end{array}$ & $\begin{array}{c}\text { Rata-rata kadar } \\
\text { amilosa pada biji } \\
\text { jagung pulut } \\
(\%)\end{array}$ \\
\hline $\mathrm{A}_{0}(0,00$ ton/ha) & $7,387^{\mathrm{a}}$ \\
$\mathrm{A}_{1}(0,75$ ton/ha) & $7,610^{\mathrm{b}}$ \\
$\mathrm{A}_{2}(1,50$ ton/ha) & $6,369^{\mathrm{c}}$ \\
$\mathrm{A}_{3}(2,25$ ton/ha) & $6,841^{\mathrm{d}}$ \\
$\mathrm{A}_{4}(3,00$ ton/ha) & $5,699^{\mathrm{e}}$ \\
$\mathrm{A}_{5}(3,75$ ton/ha) & $4,235^{\mathrm{f}}$ \\
$\mathrm{A}_{6}(4,50$ ton/ha) & $4,855^{\mathrm{g}}$ \\
\hline
\end{tabular}

Keterangan : Angka-angka yang diikuti huruf yang sama tidak berbeda nyata pada $\alpha=0,05$

Hasil uji t menunjukkan bahwa perlakuan dosis pupuk $\mathrm{A}_{5}$ memberikan rata-rata kadar amilosa terendah pada biji jagung pulut sebesar 4,235 \%. Hasil analisis regresi linear sederhana ialah sebagai berikut :

$$
\begin{gathered}
Y=7,751-0,536 X \\
R^{2}=0,826
\end{gathered}
$$

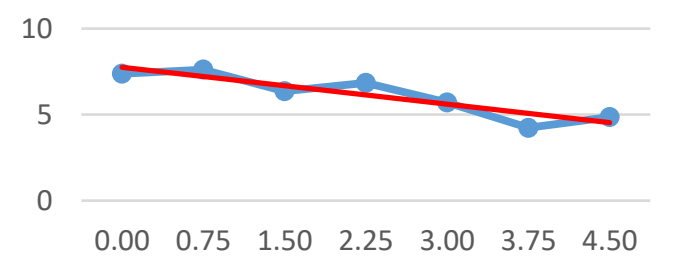

GAMBAR 8. Hubungan Dosis Pupuk dengan Kadar Amilosa pada Biji Jagung Pulut

Suarni dan Yasin (2011) menyatakan bahwa pati pada biji jagung pulut terdiri dari dua jenis polimer glukosa, yaitu amilosa dan amilopektin. Bahan yang mengandung kadar amilosa tinggi jika direbus maka amilosanya terekstrak oleh 
air panas sehingga terlihat warna putih seperti susu. Komposisi amilosa di dalam biji jagung terkendali secara genetik, umumnya biji jagung mengandung $25-30$ $\%$ amilosa. Hasil penelitian menunjukkan bahwa kadar amilosa yang terdapat dalam biji jagung pulut berkisar antara $4-7 \%$. Walaupun terkendali secara genetik, namun faktor lingkungan berupa pemupukan diduga juga mempengaruhi kadar amilosa biji jagung pulut. Semakin tinggi dosis pupuk abu sabut kelapa menyebabkan unsur kalium yang diserap tanaman semakin besar dan menyebabkan amilosa yang terbentuk di dalam pati semakin berkurang.

3) Kadar Amilopektin pada Biji Jagung Pulut

Hasil analisis varians menunjukkan bahwa perlakuan dosis pupuk organik abu sabut kelapa berpengaruh nyata terhadap kadar amilopektin biji jagung pulut. Hasil uji t 2 sampel independen ialah sebagai berikut :

TABEL 11. Rata-rata Kadar Amilopektin pada Biji Jagung Pulut

\begin{tabular}{cr}
\hline $\begin{array}{c}\text { Dosis pupuk } \\
\text { organik } \\
\text { abu sabut kelapa }\end{array}$ & $\begin{array}{c}\text { Rata-rata kadar } \\
\text { amilopektin biji } \\
(\%)\end{array}$ \\
\hline $\mathrm{A}_{0}(0,00$ ton/ha) & $92,613^{\mathrm{a}}$ \\
$\mathrm{A}_{1}(0,75$ ton/ha) & $92,390^{\mathrm{b}}$ \\
$\mathrm{A}_{2}(1,50$ ton/ha) & $93,631^{\mathrm{c}}$ \\
$\mathrm{A}_{3}(2,25$ ton/ha) & $93,159^{\mathrm{d}}$ \\
$\mathrm{A}_{4}(3,00$ ton/ha) & $94,301^{\mathrm{e}}$ \\
$\mathrm{A}_{5}(3,75$ ton/ha) & $95,765^{\mathrm{f}}$ \\
$\mathrm{A}_{6}(4,50$ ton/ha) & $95,145^{\mathrm{g}}$ \\
\hline Keterangan : Angka-angka yang diikuti huruf \\
\multicolumn{2}{c}{ yang sama tidak berbeda nyata } \\
pada $\alpha=0,05$
\end{tabular}

Hasil uji t menunjukkan bahwa perlakuan dosis pupuk $\mathrm{A}_{5}$ memberikan rata-rata kadar amilopektin tertinggi pada biji jagung pulut sebesar 95,765 \%. Hasil analisis regresi linear sederhana ialah sebagai berikut.

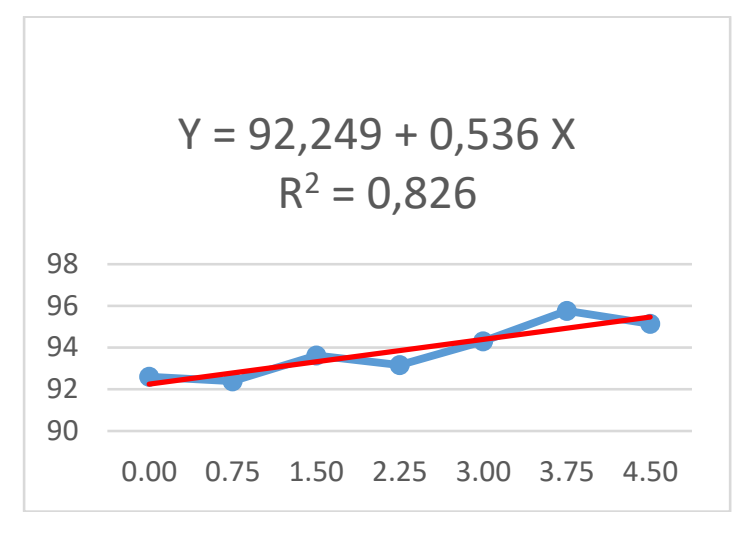

GAMBAR 9. Hubungan Dosis Pupuk dengan Kadar Amilopektin pada Biji Jagung Pulut

Amilopektin merupakan salah satu jenis polimer glukosa yang terdapat dalam pati biji jagung pulut. Adapun perbandingan komposisi amilosa dan amilopektin pada pati jagung ialah $25-30$ $\%$ amilosa dan $70-75 \%$ amilopektin, namun pada jagung pulut kadar amilopektin dapat mencapai hingga $100 \%$. Seperti halnya pada amilosa, kadar amilopektin dalam biji jagung pulut juga terkendali secara genetik. Walaupun demikian, lingkungan juga memberikan peranan dalam rangka penampakan karakter yang sebenarnya terkandung dalam gen tersebut. (Maruapey dan Faesal, 2010). Karena itu maka pengaruh faktor lingkungan seperti pemupukan abu sabut kelapa diduga juga turut berperan dalam peningkatan kadar amilopektin di dalam biji jagung pulut. Semakin tinggi kadar amilopektin maka tekstur dan citarasa jagung pulut semakin empuk, gurih, dan enak.

\section{SIMPULAN DAN SARAN}

\subsection{Simpulan}

1) Perlakuan dosis pupuk organik abu sabut kelapa berpengaruh nyata terhadap variabel tinggi kedudukan tongkol dari permukaan tanah, jumlah baris biji pada tongkol, bobot per tongkol dengan dan tanpa klobot, produksi jagung pulut dengan dan tanpa klobot, serta kadar pati, amilosa, dan amilopektin pada biji.

2) Perlakuan dosis pupuk organik abu sabut kelapa sebesar 0,75 ton/ha 
memberikan rata-rata tertinggi pada variabel tinggi kedudukan tongkol dari permukaan tanah dan jumlah baris biji pada tongkol. Dosis pupuk sebesar 2,25 ton/ha memberikan rata-rata tertinggi pada variabel bobot per tongkol dengan klobot dan tanpa klobot. Dosis pupuk sebesar 3,75 ton/ha memberikan rata-rata tertinggi pada variabel produksi jagung pulut dengan klobot dan tanpa klobot serta rata-rata kadar pati tertinggi, kadar amilosa terendah, dan kadar amilopektin tertinggi pada biji jagung.

3) Peningkatan dosis pupuk akan menyebabkan peningkatan secara kuantitas pada variabel tinggi kedudukan tongkol dari permukaan tanah, jumlah baris biji pada tongkol, bobot per tongkol dengan dan tanpa klobot, produksi jagung pulut dengan dan tanpa klobot, serta kadar pati dan amilopektin pada biji. Sedangkan peningkatan dosis pupuk menyebabkan kadar amilosa di dalam biji semakin menurun.

\subsection{Saran}

Diperlukan penelitian lanjutan mengenai aplikasi pupuk organik abu sabut kelapa pada tanah-tanah dengan tingkat keasaman tinggi seperti tanah gambut, podzolik merah kuning (PMK) dan ultisol untuk mengetahui efektivitas pupuk dalam memperbaiki sifat kimia tanah.

\section{UCAPAN TERIMA KASIH}

Ucapan terima kasih disampaikan kepada Direktorat Riset dan Pengabdian Masyarakat (DRPM) Direktorat Jenderal Riset dan Pengembangan Kementerian Riset, Teknologi, dan Pendidikan Tinggi atas pembiayaan penelitian ini melalui skema Penelitian Dosen Pemula Tahun 2017.

\section{DAFTAR PUSTAKA}

Azrai, M., M.J. Mejaya, dan M. Jasin, 2009. Pemuliaan Jagung Khusus. Balai Penelitian Tanaman Serealia. Maros.
BPS Poso, 2013. Poso dalam Angka 2013. Badan Pusat Statistik Kabupaten Poso.

Dewi, E.S. dan Tambingsila, M., 2014. Kajian Peningkatan Serapan NPK pada Pertumbuhan dan Hasil Tanaman Jagung dengan Pemberian Kombinasi Pupuk Anorganik Majemuk dan Berbagai Pupuk Organik. Jurnal AgroPet Fakultas Pertanian Universitas Sintuwu Maroso. 11(1) : 1 - 12 .

Dianawati, M., 2014. Penggunaan Pupuk Kandang dan Limbah Organik sebagai Media Tanam Produksi Benih Kentang. Jurnal Agros. 16 (2) : $292-300$.

Ekawati, I. dan Z. Purwanto, 2012. Potensi Abu Limbah Pertanian Sebagai Sumber Alternatif Unsur Hara Kalium, Kalsium, dan Magnesium Untuk Menunjang Kelestarian Produksi Tanaman. Prosiding Seminar Nasional Kedaulatan Pangan dan Energi Universitas Trunojoyo. 27 Juni 2012, Madura, Indonesia. Hal. $135-139$.

Farizaldi, 2014. Pengaruh Pemberian Pupuk Kandang dan Abu Sabut Kelapa Terhadap Pertumbuhan Sentro (Centrosema pubescens) pada Ultisol. Jurnal Penelitian Universitas Jambi Seri Sains. 16 (1) : $71-76$.

Hermawati, T., 2007. Respon Tanaman Semangka (Citrullus vulgaris Schard.) Terhadap Pemberian Berbagai Dosis Abu Sabut Kelapa. Jurnal Agronomi Fakultas Pertanian Universitas Jambi. 11 (2) : 77 - 80.

Jumin, H.B., 2010. Dasar-dasar Agronomi. Rajawali Press. Jakarta.

Kementan RI, 2011. Peraturan Menteri Pertanian RI tentang Pupuk Organik, Pupuk Hayati, dan Pembenah Tanah. Kementerian Pertanian Republik Indonesia. Jakarta. 
Lakitan, B., 2011. Dasar-dasar Fisiologi Tumbuhan. Raja Grafindo Persada. Jakarta.

Lestari, E.B., 2016. Pengaruh Kombinasi Pupuk Kandang Sapi dan Abu Sabut Kelapa sebagai Pupuk Utama dalam Budidaya Tanaman Brokoli (Brassica oleracia L.). Planta Tropica Journal of Agro Science. 4 (2) : $95-100$.

Maesaroh, S., S.M.R. Sedyawati, dan F.W. Mahatmanti, 2014. Pembuatan Pupuk $\mathrm{K}_{2} \mathrm{SO}_{4}$ dari Ekstrak $\mathrm{Abu}$ Serabut Kelapa dan Air Kawah Item. Indonesian Journal of Chemical Science. 3 (3) : 239 243.

Maruapey, A. dan Faesal, 2010. Pengaruh Pemberian Pupuk KCl Terhadap Pertumbuhan dan Hasil Jagung Pulut (Zea mays ceratina L.). Prosiding Pekan Serealia Nasional. 26 - 30 Juli 2010, Maros-Makassar, Indonesia. Hal. 315 - 326.

Nurhayati, A. Jamil, dan R.S. Anggraini, 2011. Potensi Limbah Pertanian Sebagai Pupuk Organik di Lahan Kering Dataran Rendah Iklim Basah. Jurnal Iptek Tanaman Pangan. 6 (2) : 193 - 202.

Nurmas, A., 2008. Pengaruh Abu Sabut Kelapa Sebagai Bahan Pengapuran Alternatif Terhadap Pertumbuhan dan Produksi Tanaman Mentimun pada Tanah PMK. Jurnal Warta Wiptek. 16 (2) : $79-82$.

Nurvitha. L., 2016. Pengaruh Abu dan Pupuk Kandang Terhadap Pertumbuhan dan Hasil Tanaman Ciplukan (Physalis angulata L.) pada Media Gambut. Jurnal Agrovigor. 9 (1) : $33-41$.

Oktavia, F., 2013. Peran Produk Olahan Sabut Kelapa Sebagai Penunjang Kelestarian Ekologi. Prosiding Konferensi Nasional Kelapa VIII. 21 Mei 2014, Jambi, Indonesia. Hal. $205-210$.

Pandia, A., Bangun, M.K., dan Hasyim, H., 2013. Respons Pertumbuhan dan
Produksi Beberapa Varietas

Tanaman Jagung terhadap Pemberian Pupuk $\mathrm{N}$ dan $\mathrm{K}$. Jurnal Online Agroteknologi. 1 (3) : $348-361$.

Pradana, G.B.S., T. Islami, dan N.E. Suminarti, 2015. Kajian Kombinasi Pupuk Fosfor dan Kalium pada Pertumbuhan dan Hasil Dua Varietas Tanaman Sorghum (Sorghum bicolor (L.) Moench). Jurnal Produksi Tanaman Fakultas Pertanian Universitas Brawijaya. 3 (6) : $464-471$.

Risnah, S., P. Yudono, dan A. Syukur, 2013. Pengaruh Abu Sabut Kelapa Terhadap Ketersediaan K di Tanah dan Serapan K pada Pertumbuhan Bibit Kakao. Jurnal Ilmu Pertanian Fakutas Pertanian UGM. 16 (2) : 79-91.

Soemeinaboedhy, I.N. dan R.S. Tejowulan, 2007. Pemanfaatan Berbagai Macam Arang Sebagai Sumber Unsur Hara P dan K Serta Sebagai Pembenah Tanah. Jurnal Agroteksos Fakultas Pertanian Universitas Mataram. 17 (2) : $114-122$.

Suarni, 2009. Komposisi Nutrisi Jagung Menuju Hidup Sehat. Prosiding Pekan Serealia Nasional. 26 - 30 Juli 2010, Maros-Makassar, Indonesia. Hal. 410 - 426.

Suarni, 2013. Pengembangan Pangan Tradisional Berbasis Jagung Mendukung Diversifikasi Pangan. Jurnal Iptek Tanaman Pangan. 8 (1) : $39-47$.

Suarni dan Yasin, M., 2011. Jagung Sebagai Sumber Pangan Fungsional. Jurnal Iptek Tanaman Pangan. 6 (1) : 41 - 56.

Yasin, M., Langgo, W., dan Faesal, 2014. Jagung Berbiji Putih Sebagai Bahan Pangan Pokok Alternatif. Jurnal Iptek Tanaman Pangan. 9 (2) : 1 . 